\title{
Employing Autoethnography to Examine Our Diverse Identities: Striving Towards Equitable and Socially Just Stances in Literacy Teaching and Research
}

\author{
Cynthia Helen Brock ${ }^{1}$ \\ Adeline Borti \\ Tia Frahm \\ Lori Howe \\ Dilnoza Khasilova \\ Karen Ventura-Kalen \\ University of Wyoming \\ U. S. A.
}

\begin{abstract}
This paper brings together the storied experiences of a group of diverse scholars from Ghana, Uzbekistan, and the United States who use a collaborative autoethnographic lens to engage in the process of self-reflection/self-critique with respect to salient aspects of their identities (e.g., race, language, gender, socioeconomic status, and so forth). Each scholar also explores how her identity informs and influences her attitudes, behaviors, beliefs and actions with respect to the equitable enactment of her pedagogy and research.
\end{abstract}

KEYWORDS: collaborative autoethnography, equity, diversity, pedagogy, research

The Nature of Our Collaboration Considering Equity

The Collaborators and Their Stories

Threads of Educational Equity Woven Through Our Stories

Concluding Comments Notes

References

Author Contact

"As I teach, I project the condition of my soul onto my students, my subject, and our way of being together" (Palmer, 2007, p. 2).

As teachers and researchers, we have long known that our social identities ${ }^{2}$ shape and impact our work-for better or worse (Anyon, 1980; Rist, 1970; Weis, Cipollone \& Jenkins, 2014). Historically, scholars have studied identity development and its impact on our work as educators and researchers (e.g., Helms, 1990). More recently, scholars have begun to develop a theory of intersectionality between different 
aspects of our evolving identities (Wijeyesinghe \& Jackson, 2012) that are crucial to how we experience and affect the world. Because our "social identities are shaped by social, political, cultural, geographical and historical contexts, they shift as contexts change [emphasis added]" (Goodman \& Jackson, 2012, p. 218). Thus, our identities are fluid and dynamic. By constructing contexts whereby we engage in in-depth reflection, and thoughtful self-critique, we can cultivate new and more equitable and socially just identities. In short, we can examine and nurture positive change in the multiple "selves" that comprise our identities. This matters because engaging in the process of self-reflection/self-critique with an eye towards self-improvement can positively impact our work as educators and researchers and provide a foundation from which we work to foster equity in our teaching and research (Howard, 2016).

This paper brings together the storied experiences of a group of diverse scholars from Ghana, Uzbekistan, and the United States, nested within the same university. We use a collaborative autoethnographic lens (e.g., Diversi \& Moreira, 2009; Gale \& Wyatt, 2009) to engage in the process of self-reflection/self-critique with respect to salient aspects of equity as integral to our identities. Here, individual scholars' self-reflexive vignettes are framed from different autoethnographic traditions. Each scholar explores aspects of her equity identity such as race, language, religion, gender, or socioeconomic status, and questions how identity may influence her attitudes, beliefs, and actions regarding pedagogy and research. The purpose of this paper is to illuminate ways in which different approaches to autoethnography can be used to interrogate the complex interplay of our identities with an eye towards understanding and promoting equity in education.

This paper is divided into four major sections. First, we discuss the nature of our collaboration. Second, we articulate the conception of equity we use to frame and critique our individual stories. Third, we present five identity/equity vignettes, highlighting our distinct autoethnographic approaches. Finally, we explore how our individual identity/equity vignettes might inform (a) our future individual and collective work, and (b) the field of education, in general, and literacy education, in particular. This kind of reflexive work matters because educators and researchers are more apt to engage in transformative equitable teaching and research if they critically examine and reflect on their own situated identities (Garcia, Arias, Harris, \& Serna, 2010; Howard, 2016; Ladson-Billings, 1997). Thus, our work embodies the reflexive practice we advocate for deepening and improving pedagogy and thoughtful, equitable research.

\section{The Nature of Our Collaboration}

There are myriad features of collaborative autoethnography including, but not limited to, group size, the extent and nature of collaboration, data collection approach, and writing style (Chang, Ngunjiri, \& Hernandez, 2013). As a group, we made decisions about each of these features. First, four of our six collaborators (Adeline, Tia, Dilnoza, and Karen) spent an entire semester in a literacy/diversity doctoral seminar taught by Cindy, engaging in readings and discussions, and writing individual, autoethnographic identity papers. As each scholar wrote, she discussed evolving ideas with other 
students and met with Cindy individually. Lori and Dilnoza were in another doctoral seminar and opted to write a duoethnography.

Similar to an approach used by Hernandez, Sancho, Crues, and Montane (2010), described as a partial collaboration, our six collaborators decided to write one paper featuring key aspects of each scholar's identity that (a) surfaced as especially poignant for her own identity development, and (b) illustrated some aspect of equity in her teaching and/or scholarship. We met myriad times in a whole group and in small groups across a semester. We label this collaboration as partial because the researchers "contributed in different ways to different phases of the overall process, but they did not all fully participate in the same ways with one another from beginning to end" (Chang et al., 2013, p. 42). For example, five of the scholars (Adeline, Tia, Dilnoza, Karen, and Lori) wrote identity/equity vignettes, and Cindy wrote and framed the overall paper. Each scholar engaged in careful and thoughtful reading, reflecting, discussing, and writing to select a key event. We label these events as identity/equity vignettes.

\section{Considering Equity}

During the collaborative process, it became clear that we each strive to enact equitable practices in our teaching and research. In our collaborative conversations, we explored definitions of equity, drawing on the image presented in Figure 1 and on various professional and scholarly resources.

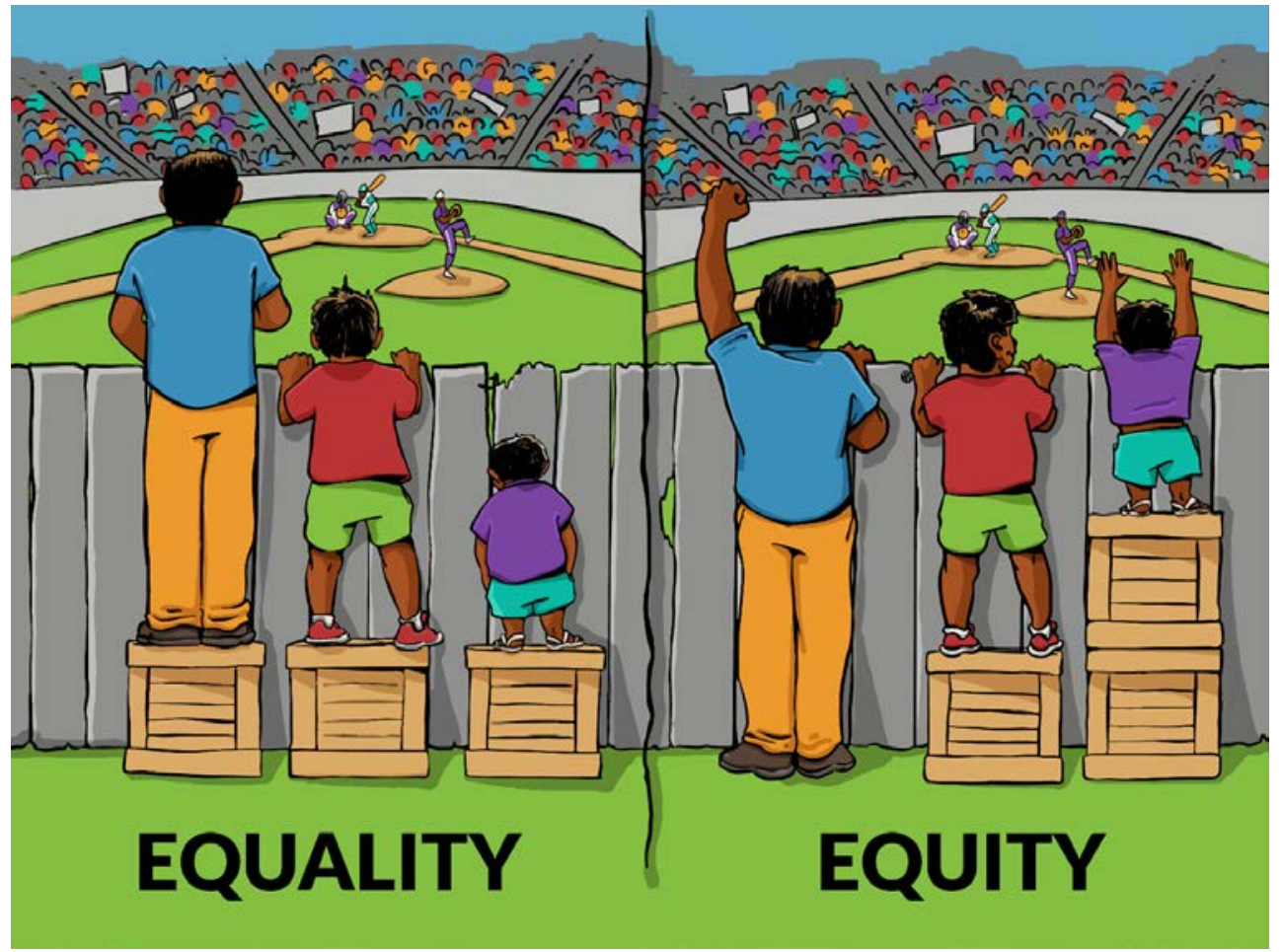

Figure 1. Conceptions of equality and equity (Maguire, 2016) 
According to Larson and Barton (2013), "Equality emphasizes providing the same (or equal) resources to all. If all students get the same resources, justice is served through equal treatment and equal opportunity" (p. 21). This is depicted in the image labeled EQUALITY in Figure 1. The EQUALITY image underscores that some students start out with more social, cultural, and material capital than others (Bourdieu \& Wacquant, 1992). The image on the right-hand side of Figure 1 represents EQUITY. When seeking to enact equitable practices, "policymakers and educators intentionally adjust a variety of resources to better serve the highest-need students.... [Educators] ...view each student-and each staff member-as an individual with needs, skills, and a background that is unique to him or her" (Larson \& Barton, 2013, p. 22).

Whereas the image in Figure 1 depicts key differences between equity and equality, scholars (e.g., Rizvi \& Lingard, 2010) argue that the term equity itself is complex and nuanced. When viewed from a "weak sense," equity refers simply to access to needed resources. Figure 1 depicts equity from the weak sense because the focus is on the material resources needed to see a baseball game. When educators view equity from a "strong sense," however, they attend to the social, cultural and historical conditions that endow some groups with more resources than others (Rizvi \& Lingard, 2010). In essence, they would seek to lower or remove the fence in Figure 1 rather than merely trying to support people striving to look over it.

A second, nuanced example of equity described by Unterhalter (2009) attends to three positions (i.e., equity from the bottom, the middle, and the top) through which equitable practices are conceptualized and enacted. For Unterhalter (2009), "equity from the bottom" refers to engagement and critique associated with individual agency. "Equity from the middle" attends to "flows of ideas, skill, material resources, and time" (p. 422). Finally, "equity from the top" refers to legal frameworks, rules, and institutions. Unterhalter argues that justly enacted equity must be rooted in all three positions. Here, each of us illuminates themes pertaining to equity via our individual autoethnographic stories, and we articulate different, nuanced ways that equity is considered and enacted.

\section{The Collaborators and Their Stories}

Whereas the overall structure of this paper is a collaborative autoethnography, the identity/equity vignettes written by each scholar vary by aspects of identity and autoethnographic framework. For example, Adeline's identity/equity vignette is analytical and narrative; she describes and analyzes a pertinent event from her past in storied form. Lori and Dilnoza's duoethnographic identity/equity vignette is dialogic and performative, employing dialogue and poems. Karen's identity/equity vignette is dialogic narrative/performative autoethnography; she represents her experience as a Poem in Two Voices (Fleischman, 1988). Tia's identity/equity vignette is autoethnographic narrative, as she describes--in storied form--a significant undergraduate experience involving equitable treatment. Each of the following literacy/equity vignettes troubles and responds to a cultural or institutionalized issue of equity. We begin with Adeline, whose story questions and reveals a pervasive lack of 
gender equity in her home country of Ghana.

\section{Ladies Are to Be Seen But Not Heard: Adeline}

About Adeline. I belong to the Ewe (Eve) ethnic group in the Volta region of Ghana. Coming from Ghana, a multilingual country with 65-90 Ghanaian languages enhanced my multilingual experiences and language identity. In addition to the Ewe language, I learned English (Ghana's official language), basic French, and German at school, and Twi and basic Ga (Ghanaian languages). As a language/literacy educator, a researcher, and a social worker, I engage in teaching and research in reading, literacy education, English language education and women's empowerment.

Silencing women. "LADIES ARE NOT HEARD BUT SEEN" was the statement drummed constantly into my ears. It was Monday, September 25, 1989, and I was seated in the assembly hall of a girls' secondary school in the southern part of Ghana. It was my first year at secondary school. I sat anxiously waiting for the new student orientation. Then, I heard my headmistress blaring, "Ladies are not heard but seen." Her admonition increased my anxiety in this new environment with new people, new rules, and new social, psychological, and academic challenges. The shout was an attempt by the headmistress to keep us quiet and encourage us to "behave like ladies." This example illustrates my experience as a girl denied the freedom of speech.

Women's language use in Ghana is limited despite the fact that multilingualism is a rich resource in Ghana (e.g., I speak four languages as do many Ghanaian women). My experience of the culture of silence illuminates the broader experience of women in Ghana (Baden, Green, Otoo-Oyortey, \& Peasgood, 1994; Prah, 2002). During discussions perceived to be "serious," women are expected to talk less or not at all because their views are not respected. As a result, women become quiet in social contexts; I myself became reluctant to contribute even meaningful, important ideas. I noticed that my female classmates exhibited similar attitudes; thus, the culture of silence was nurtured consciously or unconsciously (Sutherland-Addy, Boateng, Osei, \& Prah, 1995; Twum-Danso, 2009).

Later, I encountered similar situations during my 16 years of teaching and activism. I realized that female students were especially reluctant to engage in class discussions. As an agent for equity, I consider it a service to promote the participation of women and girls in freedom of speech and expression as enshrined in Ghana's 1992 Constitution (Article 21, Section A). My vision is to teach Ghanaian women to SPEAK RIGHT AND SPEAK OUT. I seek to break the culture of silence by facilitating women's freedom to speak in classrooms and communities. For example, I have organized "freedom of speech" sensitization workshops in several different Ghanaian communities. I look forward to working with brave and courteous African women who will speak out and make immense contributions to education, economics, law, tourism, governance, health, and other importance sectors in Ghana, in Africa, and across the globe. 
Against this background, as a researcher, I employed autoethnography to interrogate the existence and perpetuation of the culture of silence. In particular, I used estrangement autoethnography to frame my identity/equity vignette (Keenan \& Evans, 2014; Tsalach, 2013). I employed introspection to analyze my estranged position in the culture of silence, and the role of gendered language in the development of my identity (Ellis \& Bochner, 2000; Hughes, Pennington \& Markis, 2012). Using intersectionality of language and gender (Goodman \& Jackson, 2012), my identity/equity vignette presents my voice in research and the voices of Ghanaian women whose concerns about the debilitating culture of silence might not otherwise be heard.

Summary and transition. Here, Adeline illuminates the need to call to order institutions that rob women of their own voices. In the next literacy/equity vignette, Dilnoza and Lori act to disrupt patterns of institutionalized, lingual and cultural inequity in higher education. Adeline's vignette revealed a silencing of women based on a lack of gender equity in Ghana, while Dilnoza's reveals similar issues for women from the Middle East, and Lori's vignette illuminates avenues of multilingual equity in diverse writing classrooms.

\section{Multilingual Educators as Agents of Equity: Dilnoza and Lori}

For our collaboration, we chose the mystory, a qualitative approach nested inside interpretive autoethnography, uncovering stories that often go unheard. As explained by Denzin (2013), "The mystory... presumes that the social order has to change if problems are to be successfully resolved.... If the status quo is maintained...then the systemic processes producing the problem remain in place" (p. 134). In our teaching and research, we support students whose status as non-native English speakers often results in unequal access to resources and opportunities.

Here, mystories illuminate our goals as agents for equity in higher education. Duoethnography, "a form of ethnography in which the lived experiences of two researchers work in tandem to examine a cultural phenomenon" (Creswell, 2013), allows us to creatively interrogate the connections between our mystories, deepening our understanding of the issue and informing our work. According to Denzin (2013), the mystory is "simultaneously a personal mythology, a public story, a personal narrative, and a performance that critiques...filled with sounds, music, poetry, and images taken from the writer's personal history.... It locates itself against the...larger society (p. 133).

About Dilnoza and Lori. My name, Dilnoza, comes from the Persian language, meaning "kind and gentle soul." I am a "vostochnaya devushka" (from Russian "eastern girl") Uzbek graduate student researcher. I am olive-skinned, black-haired and hazeleyed, born in Ivanovo, Russia, to Uzbek parents. Russian and Uzbek cultures and languages are as familiar to me as my own skin. These are the roots of my bilingualism and my desire to build bridges between cultures. Today, I am a doctoral student in Literacy, focusing on the transferability of multilingualism (Nieto, 2010). I founded the World Language and Culture Center project, a program serving more than 250 faculty, 
staff, and students. This project is free, and volunteers introduce basic languages skills and awareness of their countries.

I am Lori, a 45-year-old American poet, teacher, researcher. I am fair-skinned, blonde-haired and blue-eyed, the visible product of my English paternal ancestors, though through maternal lines I am 1/8 Cherokee. My family is monolingual English, White, and Appalachian. As a doctoral candidate in Literacy, I teach students who struggle with writing. ELL students face the added challenge of learning in English, along with those faced by their English-speaking peers (Macedo \& Bartolomé, 2014; Scott, Straker, \& Katz, 2008). I work against cultural stereotyping to help all students thrive.

Following, we offer both a vignette and a poem that illuminate of our work. The goal of these mystories is to offer pedagogical approaches that embody equity of access in higher education.

Vignette 1: Dilnoza and building bridges of cultural equity. A shy smile greets me as I sit down. Laila wears a long, black dress embroidered in gold; her headscarf frames a lovely face with intelligent eyes. Laila has sought me out for help improving her English. As we chat in Arabic and English about an essay on women's success, I realize "women's success" may have myriad cultural definitions.

Dilnoza: Laila, could you write an essay similar to this one, about your own successes?

Laila: What does this word "success" mean?

Dilnoza: Good question! Let's find the translation.

Laila: Here it is. Our word is "najah." I finished high school, and then got married. Today, I have my children.

Dilnoza: What do you think being a mom, wife, and sister equates to in your culture?

Laila: It is my "success.'

Dilnoza: Yes, taking care of family and graduating from high school is your success. Do you know, this word has different definitions, depending on each person's life?

Laila: For my life, I think this is my success.

Dilnoza: Exactly. And you say you want to learn English so you can find a good job and continue your education. Why?

Laila: Future success.

In the above excerpt, Laila explained to me that "success" for her in her culture includes being married and having children. I agree. When I asked Laila why she was studying English, Laila indicated that her future-oriented definition of success, as she lived and studied in the United States, included learning English and getting a good job. Equity emerges as a cornerstone of our interactions as I taught Laila English; both Laila and I understood that proficient English is a key component of Laila's future-oriented definition of "success." 
Vignette 2: Lori and building bridges of language equity. Esmeralda and Lourdes, willowy, dark-haired students in my English 1010 class, sit across from my desk. Esmeralda's dark brown eyes are filled with worry.

Esmeralda: Professor, we can't write poetry in English. We have to drop.

Lourdes: Is the same for Paloma and Miguel. They drop your class too. Poetry is ok, but not to write in English.

Lori: Here's an idea. You have a skill most of your classmates don't have-you can write poems in Spanish.

Lourdes: We can write in Spanish?

Lori: In Spanish AND English—and everyone will do it. Will you help me make an assignment?

Esmeralda: How can we? It's confusing.

Lori: You can help each other with words. You speak English, but most of your classmates don't speak any Spanish. Will you help them?

(The following poem is a conflation of several. The theme was "What is persistence?")

\author{
Me Toca-It's My Turn \\ Persistance significa que I won't stay in bed, \\ durmiendo after trabajando el night shift \\ again, o cuando mi grandfather coughs all night \\ in his suenos, where the war lives. \\ Persistence significa FIGHT- \\ por honor, for mi familia. \\ Soy the flower que florece in the desert. \\ Pablo Neruda dice que he was tired \\ of being a man, \\ but I say, ME TOCA- \\ escucha! I say, \\ it's my turn now. \\ Mira! \\ Soy the flower que florece in the desert.
}

The above dialogue excerpt and poem demonstrate our desire to serve as agents of equity in higher education. Equity lies at the heart of these discussions of "success" and "persistence." Dilnoza's work with Laila underscores how language supports equity for ELL students (Garcia, 1995). Similarly, Lori's poetry assignment, coconstructed by English- and Spanish-speaking students, positioned them to teach and learn together, framing all language skills as cultural capital (Lu \& Horner, 2013). Fluency may allow Dilnoza's student to inhabit with greater confidence those political and cultural spaces that remain tacitly off-limits to non-English speakers (Myles \& 
Cheng, 2003). Lori's students, working as language partners, broke the paradigm of English as the only language of use and access (Flores \& Rosa, 2015; Lo Bianco, 2014).

Building bridges of experience with English Language Learners is an act that Langness (2003; 2004) calls "making peace." In doing this, according to Rexach (2016), academic skills are used "in combination with individual strengths and skillsets (academic, artistic, and peacemaking) to consider how we can serve as agents of equity in our own communities" (p. 26). These personal experiences illustrate our efforts to harness the power of creativity and support equity in higher education.

Summary and transition. While Dilnoza's and Lori's examples are situated inside the institution, Karen's vignette, below, interrogates internal and external, shifting cultural and lingual identities that relate to belonging, access, and self.

\section{Aquí estoy, aguantando -- Here, I Stand: Karen}

About Karen. I am a non-traditional PhD candidate. Born into a poor MexicanAmerican community and multiethnic neighborhood on Chicago's Near West Side, I identify as Latina. However, the intersectionality of my Mexican-American heritage, and assimilation as a third-generation heritage language learner, offers insight into issues of lingual and cultural equity, specifically gain in the form of socio-economic status and academic privilege but also disequilibrium, resulting in a sense of loss of language and culture and ultimately identity. I am currently exploring how this disequilibrium impacts my approach to academic research.

Exploring multiple identities. Recently, I suffered a humbling experience while making a presentation to a group of people whose first language is Spanish. No one did or said anything to cause me distress, nor did they know what I was feeling. The Poem for Two Voices (Fleischman, 1988) below is an attempt to convey my sense of displacement due to tension and bumping points (Cardinal, 2011) between my MexicanAmerican and third-generation American identities. This performative format enabled me to engage in reflexive autoethnographic dialogue germinating from the intersectionality of my varied discourses (Gee, 1989, 2011) and lived experiences (Larkin, Watts, \& Clifton, 2006; Smith, 2004). The heart of this poem is the lived interrogation of equity of access as determined by linguistic identities.

Table 1

Karen's Poem for Two Voices (Fleischman, 1988)

\begin{tabular}{|l|l|l|}
\hline $\begin{array}{l}\text { I am here, } \\
\text { In corporeal form }\end{array}$ & In front of $\ldots$ & $\begin{array}{l}\text { Wam a disembodied specter, } \\
\text { Watching ... myself }\end{array}$ \\
$\begin{array}{l}\text { People, I do not know, } \\
\text { Nor they me }\end{array}$ & $\begin{array}{l}\text { People, from whom I feel } \\
\text { displaced }\end{array}$ \\
\hline
\end{tabular}




\begin{tabular}{|c|c|c|}
\hline $\begin{array}{l}\text { Everyone is fluent, except } \\
\text { me ... } \\
\text { In one language, Spanish } \\
\text { Less comfortable in another ... } \\
\text { El ingles, mi lengua } \\
\\
\text { My companions' countenance, } \\
\text { Their names } \\
\text { Belie they are of me ... } \\
\text { And I of them, } \\
\text { Culturally, linguistically, } \\
\text { ethnically } \\
\\
\text { I dressed carefully, } \\
\text { Professionally } \\
\text { I practiced my presentation ... } \\
\text { I feel prepared } \\
\\
\text { I stand, up front } \\
\text { Sharing my slides } \\
\text { Clicking ever forward } \\
\text { Talking, } \\
\text { Proffering information } \\
\text { So carefully prepared } \\
\text { Thinking, } \\
\text { The hours spent, } \\
\text { The recursive editing, enables } \\
\text { My presentation to convey the } \\
\text { right tone, } \\
\text { The right information } \\
\text { It is meaningful } \\
\text { Silent and still, they listen } \\
\text { En mi lenguaje, } \\
\text { El idioma predominante de este } \\
\text { país } \\
\text { That is, by birth } \\
\text { Foreign to them }\end{array}$ & $\begin{array}{c}\text { We are all Latina } \\
\text { /o } \\
\text { Olive to brown } \\
\text { skinned } \\
\text { Dark eyed } \\
\text { Dark colored hair } \\
\text { Corporal } \\
\text { similarities }\end{array}$ & $\begin{array}{l}\text { Spanish is my heritage } \\
\text { language } \\
\text { Shamefully, one never quite } \\
\text { conquered } \\
\text { A language that is, and is } \\
\text { not ... } \\
\text { Mi lengua } \\
\text { Culturally, ethnically - similar } \\
\text { My disembodied specter } \\
\text { murmurs, } \\
\text { "You are an outsider" } \\
\text { My specter sees this ... } \\
\text { Knows this ... } \\
\text { Feels this } \\
\text { As soon as I stand, and begin } \\
\text { Everything feels wrong, } \\
\text { My clothes, my choice of } \\
\text { words, } \\
\text { My spoken language ... } \\
\text { English } \\
\text { I stand, alone } \\
\text { Sweating, profusely } \\
\text { Speaking, at first, too fast } \\
\text { Then, too slowly } \\
\text { Modulating my voice, } \\
\text { Like someone speaking under } \\
\text { water } \\
\text { Heavy beads of perspiration } \\
\text { collect on my brow } \\
\text { Sweat pools, under my clothes } \\
\text { I am drenched, clammy } \\
\text { My face, beet red } \\
\text { Lo que digo no tiene sentido } \\
\text { I speak, }\end{array}$ \\
\hline
\end{tabular}




\begin{tabular}{|l|l|}
\hline I know who I am & \\
No longer a child of the ghetto, & In a language, English \\
Or the slums & That is both \\
I am Privileged, & My first \\
Middle class & And second language \\
PhD Candidate & I (re)discover who 'I am not" \\
Academic & In this moment, I know \\
Researcher & What has been lost \\
Honored to be here & My former self / selves \\
& My identity \\
Mientras aguanto, sola, & Strained through a sieve \\
Aquí estoy, & All the discourses of my life \\
De forma corporal & Strained and reduced, \\
Soy una de ellos & Amidst the intersectionality of \\
& multiple identities \\
& I am not here, \\
I am, instead, \\
A disembodied specter \\
& Soy una intrusa - an outsider \\
\hline
\end{tabular}

I chose narrative/performance autoethnography to present, represent, and critique my identities after reading Alexie's (2002) Porcupines and China Dolls. We cannot understand or write someone's story without understanding "where they came from" (p. 4). I find it difficult to write someone's story without first knowing how I fit, based on my own lived experiences and intersecting identities, into the storyline (Shields, 2008). Using a narrative / performative autoethnographic approach helped me understand my own story through "an ordering of relationships, memories, possibilities, an attempt to come to terms with the past, an attempt to find the future" (King, 2003, p. 117).

Summary and transition. Autoethnography helped Karen reflexively self-critique her own lived "experiences and interactions with others...to achieve wider cultural, political or social understanding" (Pace, 2012, p. 2). This politicized aspect of access and equity is also reflected in Tia's vignette as a first-generation student teacher.

\section{An Unlikely Academic: Tia}

About Tia. I am an unlikely academic. I grew up in a small town in the Midwest and was raised by divorced parents, grandparents, and great-grandparents; today the majority of my family resides in the same county where I graduated high school. As a first generation college student, I had a mentor, Dr. E., who guided me through my student teaching and into my first teaching position, and now, as a mentor myself, I strive to encourage and support students as they navigate academia. 
Mentored and mentoring. I began my student teaching in the fall semester of 2006 at an affluent elementary school in a mid-western city. Eager to put my coursework into practice, I arrived early on my first day of student teaching in a fifth grade classroom, but was told to sit on a stool in the back corner, wait for students to arrive, and to observe but not interrupt. During my third week, I taught a math lesson for a formal observation by my supervisor, Dr. E, with only a few minutes' notice. I was nervous but determined to do well. I received satisfactory remarks from Dr. E. who said to let him know if I had any further questions.

In the middle of my sixth week of student teaching, I went in distress to Dr. E.'s office and immediately burst into tears. Dr. E. patiently found some tissues and waited for me to cry it out. I told him about (a) the constant criticism of how I interacted with students (i.e., by asking about their interests and checking in with how they were doing), and (b) sitting on a stool in the back of the classroom, unable to teach. I explained that this chipped away at my desire to be a teacher. He reassured me but, by the end of that week, my cooperating teacher had ordered me to leave the classroom permanently.

Dr. E. went to bat for me, and I was reassigned to a different classroom, successfully completing my student teaching the day before graduation. Dr. E. asked me what I would take from this experience. I responded: "If I ever have a pre-service teacher in my classroom, I will serve as her mentor to the best of my ability." Now that I mentor pre-service teachers, I reflect back on the support Dr. E. provided and try to do the same for them, as I understand the impact mentorship can have for students from low socio-economic backgrounds.

The mentor/mentee relationship is valuable for students, providing equitable access to resources, networking, and assistance in navigating academia (Jones \& Goble, 2012; Putsche, Storrs, Lewis, \& Haylett, 2008). A mentor/mentee relationship that fosters trust between the two parties creates social capital (Gaddis, 2012). This social capital is particularly beneficial for first-generation college students, supporting academic achievement and increasing the likelihood of graduation (DeFreitas \& Bravo, 2012; Gaddis, 2012; Soria \& Stebleton, 2012). Helping first generation college students build social capital is one crucial way to enact equitable practices in higher education. Had it not have been for my relationship with Dr. E. and the manner in which he helped me to build social capital, I would have dropped out of the university.

I relied on autoethnographic narrative (Clandinin \& Connelly, 2000) to convey my experience during student teaching. "Autoethnography involves a critical study of yourself in relation to one or more cultural context(s)" (Reed-Danahay, 1997, p. 9).

Summary and transition. Through autoethnographic narrative, Tia reveals her experience as a first generation college student from a low socioeconomic background, positioned within the literature on the importance of mentors and mentor programs and engaging in relationships of equity. Throughout all five vignettes, written by women who are doctoral students and candidates, teachers, and scholars from extraordinary disparate backgrounds and experiences, runs the problematic question of equity of access in higher education-as well as agentive, meaningful answers-via autoethnographic approaches. 


\section{Threads of Educational Equity Woven through Our Stories}

As educators and scholars, we are attracted to autoethnography that directs us to interrogate and critique our "selves" as windows into society (Hughes \& Pennington, 2017). We are especially drawn to collaborative authethnography that "focuses on selfinterrogation but does so...cooperatively within a team of researchers" (Chang et al, 2013 , p. 21). Here, we discuss two central themes that cut across our identity/equity vignettes. First, we explore how our respective stories illustrate the building of bridges to more equitable futures. Second, we examine our roles as agents of equity relative to our individual stories.

\section{Building Bridges to More Equitable Futures}

A central theme that cuts across all of our identity/equity vignettes is that each scholar seeks to build bridges towards more equitable futures. In doing so, each scholar addresses complex and nuanced conceptions of equity as described by Rizvi and Lingard (2010) and Unterhalter (2009). For example, Lori and Dilnoza promote meaningful engagement with their students helping to connect them to higher education practices in the United States. In essence, foregrounding "equity from the middle" as described by Underhalter (2009), they ensured that the norms of their college classrooms "worked" for all students. As well, however, they engaged in "equity from the bottom" (Unterhalter, 2009) because their work promoted dialogue and critique of their practices seeking to promote individual agency for each student. Their instruction stands in stark contrast to hegemonic institutional practices that ignore the needs of students from diverse backgrounds in accessing the interactional norms common in U.S. college classrooms.

Adeline's vignette illustrates how she promotes women's individual agency and voice in her classroom instruction in Ghana, engaging in "equity from the bottom" (Unterhalter, 2009). However, through her work, she also challenges hegemonic cultural norms that silence women. Thus, she attends to "equity from the middle," questioning the flow of ideas (by arguing that women have valuable contributions to make in society) and "equity from the top" as she seeks to change the very cultural norms that silence and devalue women.

In her vignette, Tia illustrated how Dr. E. helped to build a bridge from her background and experiences to a career as a teacher. Tia, in turn, strives to follow the example provided by Dr. E. to build successful college experiences with university students. Whereas Tia's autoethnography foregrounds "equity from the middle" (Unterhalter, 2009) because it highlights the manner in which Dr. E. shaped the flow of ideas, skills, and material resources, it also represents "equity from the bottom" because Dr. E. worked with her to promote her individual agency-a practice she, in turn, enacts with her students. 
Finally, Karen's vignette illustrates the bridges that she strives to build across her various identities. By engaging in this complex identity work, Karen positions herself to aid others as they build bridges across their own different identities. Because she explores and critiques her evolving linguistic selves, Karen's work represents "equity from the bottom" (Unterhalter, 2009). However, since she sees her work as a foundation for meaningful interactions with others, Karen's work also represents "equity from the middle" in relationships between identity and the flow of ideas, skills, and resources.

Individually and collectively, these identity/equity vignettes illustrate bridge building to more equitable futures. They reflect Rizvi and Lingard's (2010) notion of equity from a 'strong sense' because they attend to the social, cultural and historical conditions that endow some groups with more resources than others. Rizvi and Lingard's (2010) notion of equity from a strong sense is similar to Unterhalter's (2009) notion of equity from the top. As well, both individually and collectively, these identity/equity vignettes reveal how we, as educators and scholars, engage in personal transformative work that (a) addresses individual agency, and (b) contests institutional/societal structures that withhold equitable treatment of individuals. Consequently, we argue that these stories meet Unterhalter's (2009) criteria for justly enacted equity - which includes equity rooted in all three positions: equity from the top, middle and bottom.

\section{Our Roles as Agents of Equity Relative to Our Individual Stories}

Across our identity/equity vignettes, there exists a pivotal point whereby we each served as agents of equity; either we were the initial agents of equity (e.g., Dilnoza, Lori, Karen, and Adeline) or had the role modeled for us (e.g., the case of Tia's identity/equity vignette) and then became an agent of equity. For example, Dr. E. was the agent of equity for Tia. Had it not been for Dr. E., Tia would have dropped out of the university according to her. As a result of her experience, Tia has studied coaching, and she strives to be an agent of equity for her own university students. In her discussion with Laila, Dilnoza served as an agent of equity teaching Laila the literal meaning of the word success and also helping Laila to understand how success might be instantiated in a U.S. cultural context. Lori served as an agent of equity because she changed the use of language in her classroom to include Spanish as a valued language and Spanishspeaking students became co-teachers. Karen's thoughtful exploration of her own complex language situation illustrates that she was an agent of equity in her own life, as well as for others who have experienced loss of language and culture. Adeline demonstrates her role as an agent of equity in Ghana. By telling her story of estrangement, and putting her beliefs into action, she seeks to open up an empowering space for women and girls in Ghana to speak and be heard.

Collectively, we purport that our roles reveal equity from a "strong sense," as discussed by Rizvi and Lingard (2010); within our identity/equity vignettes, each of us explores and critiques conditions that endow some groups with more social, cultural, and materials resource than others, whether it be women and girls in Ghana, or heritage 
and/or English language learners or first-generation college students from low socioeconomic backgrounds in the United States Most importantly, each of us acts on her self-critique in her own immediate context, striving to make those contexts more equitable.

\section{Concluding Comments}

As a method, autoethnography helped us to mine "data from [our] own life stories as situated in sociocultural contexts in order to gain...understanding[s] of society through the unique lens[es] of self" (Chang et al., 2013, p. 18). Autoethnography provided a vehicle to interrogate our own experiences (Ngunjiri, 2014) and "reduce power differentials" (Ngunjiri, 2014, p. 622) by making ourselves vulnerable (Behar, 1993). "Democratizing inquiry" (Ngunjiri, 2014, p. 622) helps level the playing field between researcher and participant because it shapes how a story unfolds, through constant reflexive self-critique, challenging what we think we know about others, but also about ourselves (Hughes \& Pennington, 2017).

In order to highlight the potential power of self-critique/self-reflection in autoethnography, we began this paper with a quote from renowned educator and scholar Parker Palmer (2007). We return full circle to Palmer (2007) having engaged in his invitation, as educators and scholars, to explore our own inwardness. In conjunction with Palmer (2007), and other scholars (e.g., Walsh, 1999) we, as teachers and researchers, have engaged in inner exploration with an eye towards improving the manner in which we seek to act meaningfully and equitably in, and on, the world.

\section{Notes}

1. The authors are listed alphabetically; they each contributed equally to the development of this article.

2. Drawing on the work of Alvermann (in press) and Gee (2015), we define people's identities as socially constructed, multiple, and fluid.

3. The authors of this paper wish to thank Lori Howe for her careful and thoughtful editing of our paper and Joe Russo for revising and editing our references.

\section{References}

Alexie, R. A. (2002). Porcupines and China dolls. Toronto, ON: Stoddart.

Alvermann, D. (in press). Literacies and identity. New York, NY: Springer Meteor.

Anyon, J. (1980). Social class and the hidden curriculum of work. Journal of Education, 162(1), 67-92. 
Baden, S., Green, C., Otoo-Oyortey, N., \& Peasgood, T. (1994). Background paper on gender issues in Ghana. (Report No. 19). Brighton, UK: Institute of Development Studies at the University of Sussex.

Bourdieu, P., \& Wacquant, (1992). An invitation to reflexive sociology. Chicago, IL: University of Chicago Press.

Cardinal, T. (2011). Stepping-stone or saving story? LEARNing Landscapes, 4(2), 7991.

Chang, H., Ngunjiri, F. W., \& Hernandez, K. C. (2013). Collaborative autoethnography. Walnut, CA: Left Coast Press.

Clandinin, D. J., \& Connelly, F. M. (2000). Narrative inquiry: Experience and story in qualitative research. San Francisco, CA: Jossey-Bass Publishers.

Constitution of the Republic of Ghana (1993). http://www.refworld.org/docid/ 3ae6b5850.html

Creswell, J. W. (2013). Qualitative inquiry and research design: Choosing among five approaches. Los Angeles, CA: Sage Publications.

DeFreitas, S. C., \& Bravo, A. Jr. (2012). The influence of involvement with faculty and mentoring on the self-efficacy and academic achievement of African American and Latino college students. Journal of the Scholarship of Teaching and Learning, 12(4), 1-11.

Denzin, N. K. (2013). Interpretive autoethnography. In S. H. Jones, T. E. Adams, C. Ellis, (Eds.), Handbook of autoethnography, (pp. 123-142). San Francisco, CA: Left Coast Press.

Diversi, M. \& Moreira, C. (2009). Betweener talk: Decolonizing knowledge production, pedagogy and praxis. Thousand Oaks, CA: Sage Publications.

Ellis, C., \& Bochner, A. P. (2000). Autoethnography, Personal narrative, reflexivity. In N. K. Denzin \& Lincoln Y.S. (Eds.), Handbook of Qualitative Research, (2nd ed.), pp. 733-768. Thousand Oaks, CA: Sage Publications.

Fleischman, P. (1988). Joyful noise: Poems for two voices. New York, NY: HarperCollins.

Flores, N., \& Rosa, J. (2015). Undoing appropriateness: Raciolinguistic ideologies and language diversity in education. Harvard Educational Review, 85, 149-171.

Gaddis, S. M. (2012). What's in a relationship? An examination of social capital, race, and class in mentoring relationships. Social Forces, 90(4), 1237-1269.

Gale, K., \& Wyatt, J. (2009). Between the two: A nomadic inquiry into collaborative writing and subjectivity. Newcastle-Upon-Tyne, England, U.K.: Cambridge Scholars Press.

Garcia, E. (1995). The education of linguistically and culturally diverse students: Effective instructional practices. In G. Gonzales \& L. Maez (Eds.), Compendium of research on bilingual education (pp. 113-115). Washington, DC: The George Washington University, National Clearinghouse for Bilingual Education. 
Garcia, E., Arias, M. B., Harris Murri, N. J., \& Serna, C. (2010). Developing responsive teachers: A challenge for a demographic reality. Journal of Teacher Education, 61(12), 132-142.

Gee, J. (1989). Literacy, discourse, and linguistics: Introduction. The Journal of Education, 171(1), 5-176.

Gee, J. P. (2011). An introduction to discourse analysis: Theory and method. New York, NY: Routledge.

Gee, J. P. (2015). Social linguistics and literacies: Ideology in discourses (5 ${ }^{\text {th }}$ ed.). London, England: Routledge.

Goodman, D. J., \& Jackson, B. W. (2012). Pedagogical approaches to teaching about racial identity from an intersectional perspective. In C.L. Wijeyesinghe, \& B.W. Jackson (Eds.). New perspectives on racial identity development. (pp. 216-239). New York, NY: New York University Press.

Helms, J. E. (Ed.). (1990). Black and white racial identity: Theory, research and practice. Westport, CT: Greenwood Press.

Hernandez, F., Sancho, J., Creus, A., \& Montane, A. (2010). Becoming university scholars: Inside professional autoethnographies. Journal of Research Practice, 6(1), $1-15$.

Howard, G. (2016). We can't teach what we don't know: White teachers, multiracial schools (2nd. ed.). New York, NY: Teachers College Press.

Hughes, S., \& Pennington, J. L. (2017). Autoethnography: Process, product, and possibility. Thousand Oaks, CA: Sage Publications.

Hughes, S., Pennington, J., \& Markis, S. (2012). Translating autoethnography across the AERA standards: Toward understanding autoethnographic scholarship as empirical research. Educational Researcher, 41, 209-219.

Jones, M. M., \& Goble, Z. (2012). Creating effective mentoring partnerships for students with intellectual disabilities on campus. Journal of Policy and Practice in Intellectual Disabilities, 9(4), 270-278.

Keenan, J., \& Evans, A. (2014). The use of estrangement autoethnography in higher education teaching. Worcester Journal of Learning and Teaching, 9, 118-127.

King, T. (2003). The truth about stories: A native narrative. Minneapolis, MN: University of Minnesota Press.

Ladson-Billings, G. (1997). For colored girls who have considered suicide when the academy's not enough: Reflections of an African American woman scholar. In A. Neumann, \& P. Peterson (Eds.). Learning from our lives: Women, research and autobiography in education (pp. 52-70). New York, NY: Teachers College Press.

Langness, T. (2003). Making peace, a full-circle learning conflict resolution supplement. Los Angeles, CA: Children's Enrichment Program.

Langness, T. (2004). Leaders of the future, children's enrichment program. Full-Circle Learning Annual Report 2003-2004. Topanga, CA: Full-Circle Learning. 
Larkin M., Watts S., \& Clifton E. (2006). Giving voice and making sense in interpretative phenomenological analysis. Qualitative Research in Psychology, 3, 102-120.

Larson, R., \& Barton, R. (2013), Lessons on leading for equity. Principal Leadership, April, 19-24.

Lo Bianco, J. (2014). A celebration of language diversity, language policy, and politics in education. Review of Research in Education, 38, 312-331.

Lu, M., \& Horner, B. (2013). Translingual literacy, language difference, and matters of agency. College English, 75, 582-607.

Macedo, D., \& Bartolomé, L. I. (2014). Multiculturalism permitted in English only. International Multilingual Research Journal, 8, 24-37.

Maguire, A. (2016). This image is free to use with attribution: "Interaction Institute for Social Change | Artist: Angus Maguire." Online link: interactioninstitute.org and madewithangus.com

Myles, J., \& Cheng, L. (2003). The social and cultural life of non-native English speaking international graduate students at a Canadian university. Journal of English for Academic Purposes, 2, 247-263.

Ngunjiri, F. (2014). Voice and representation: Collaborative autoethnography as method for studying african leadership and management realities. In. M. Acquaah \& K. Stanz (Eds.). Sustainable development in Africa through management theory, research and practice (pp. 621-633). Greensboro, NC: Africa Academy or Management.

Nieto, S. (2010). Language, culture, and teaching: Critical perspectives for a new century ( $2^{\text {nd }}$ ed.). New York, NY: Routledge.

Pace, S. (2012). Writing the self into research: Using grounded theory analytic strategies in autoethnography. TEXT: Journal of Writing and Writing Courses, Special Issue, 13, 1-15.

Palmer, P. (2007). The courage to teach: Exploring the inner landscape of a teacher's life. San Francisco, CA: John Wiley \& Sons.

Prah, M. (2002). Gender issues in Ghanaian tertiary institutions: Women academics and administrators at Cape Coast University. Ghana studies, 5, 83-122.

Putsche, L., Storrs, D., Lewis, A. E., \& Haylett, J. (2008). The development of a mentoring program for university undergraduate women. Cambridge Journal of Education, 38(4), 513-528.

Reed-Danahay, D. (Ed.). (1997). Auto-ethnography: Rewriting the self and the social. Oxford: Berg.

Rexach, M. (2016). Sudanese children of immigrants: A tapestry unravels. Multilingual Educator, 24-27. Retrieved from http://www.bilingualeducation.org/ME/ME2016.pdf

Rist, R. (1970). Student social class and teacher expectations: The self-fulfilling prophecy in ghetto education. Harvard Educational Review, 70(3), 257-301.

Rizvi, F., \& Lingard, B. (2010). Globalizing education policy. New York, NY: Routledge. 
Scott, J. C., Straker, D. Y., \& Katz, L. (2008). Affirming students' right to their own language: Bridging language policies and pedagogical practices. Ipswich, MA: Routledge.

Soria, K. M., \& Stebleton, M. J. (2012). First-generation students' academic engagement and retention. Teaching in Higher Education, 17(6), 673-685.

Shields, S. A. (2008). Gender: An intersectionality perspective. Sex Roles: A Journal of Research, 59(5), 301-311.

Smith, J.A., (2004). Reflecting on the development of interpretive phenomenological analysis and its contribution to qualitative research in psychology. Qualitative Research in Psychology, 1(1), 39-54.

Sutherland-Addy, E., Boateng, B., Osei, J., \& Prah, M. (1995). Study on developing feasible strategies to increase female participation in tertiary education, particularly science and technology. (Interim Report) Accra, GH: The Development and Women's Studies Programme, Institute of African Studies, University of Ghana, Legon.

Tsalach, C. (2013). Between silence and speech autoethnography as an othernessresisting practice. Qualitative Inquiry, 19(2), 71-80.

Twum-Danso, A. (2009). The construction of childhood and the socialization of children in Ghana. A Handbook of children and young people's participation, 133-140.

Unterhalter, E. (2009). What is equity in education? Reflections from the capability approach. Studies in Philosophy and Education, 28(5), 415-424.

Walsh, R. (1999). Essential spirituality: The seven central practices to awaken heart and mind. New York, NY: John Wiley \& Sons.

Weis, L., Cipollone, K., \& Jenkins, H. (2014). Class warfare: Class, race, and college admissions in top-tier secondary schools. Chicago, IL: University of Chicago Press.

Wijeyesinghe, C., \& Jackson, B. (2012). New perspectives on racial identity development: Integrating emerging frameworks $\left(2^{\text {nd }}\right.$ ed.). New York, NY: New York University Press.

\section{Author Contact}

Cynthia Helen Brock: cynthia.brock@uwyo.edu

University of Wyoming, 1000 E. University Ave. Laramie, WY 82071, USA

Adeline Borti: aborti@uwyo.edu

University of Wyoming, 1000 E. University Ave. Laramie, WY 82071, USA

Tia Frahm: tfrahm@uwyo.edu

University of Wyoming, 1000 E. University Ave. Laramie, WY 82071, USA 
Lori Howe: Ihowe@uwyo.edu

University of Wyoming, 1000 E. University Ave. Laramie, WY 82071, USA

Dilnoza Khasilova: dkhasilo@uwyo.edu

University of Wyoming, 1000 E. University Ave. Laramie, WY 82071, USA

Karen Ventura-Kalen: kventura@uwyo.edu

University of Wyoming, 1000 E. University Ave. Laramie, WY 82071, USA 